\title{
MULTICULTURALISMO DE NEGAÇÃO: UM OLHAR PARA A REALIDADE DA PRISÃO DA MULHER ESTRANGEIRA
}

\section{MULTICULTURALISM OF NEGATIVE: A LOOK AT THE REALITY OF FOREIGN WOMEN'S PRISON}

Raquel Fabiana Sparemberger1

José Elias Gabriel ${ }^{2}$

RESUMO: O presente artigo objetiva realizar um estudo sobre a segregaçâo da mulher estrangeira no sistema penitenciário brasileiro. Apesar da existência do reduzido número absoluto de mulheres estrangeiras presas quando comparado ao universo das presas nacionais, a prisăo produz iguais ou piores efeitos da prisăo e resulta na negaçăo da cultura da estrangeira que cumpre pena. Algumas iniciativas apontam para a possibilidade de superaçâo dessas dificuldades de afirmaçâo do multiculturalismo, inscrevendo-se como iniciativas positivas que podem ser reproduzidas nos ambientes de privaçăo de liberdade de mulheres. A metodologia baseia-se, especialmente, na pesquisa bibliográfica, que possibilitou o suporte teórico para o desenvolvimento das ideias aqui lançadas. $O$ método de abordagem adotado foi o indutivo.

PALAVRAS-CHAVE: prisāo; Mulher; Estrangeira; Multiculturalismo.

ABSTRACT: The present paper aims to perform a study about foreign woman segregation in the Brazilian penitentiary system. Although the small number of arrested foreign women, in comparison to the number of arrested Brazilian women, the penitentiary causes equal or even worse effects and results in denial of the foreign woman culture. Some actions go towards the possibility of overcoming those adversities in accepting the multiculturalism, and they have been considered as positive actions that can be reproduced in the setting of

$1 \quad$ Pós-doutora em Direito pela Universidade Federal de Santa Catarina - UFSC. Doutora em Direito pela Universidade Federal do Paraná - UFPR. Mestre em Direito pela UFPR. Possui Graduaçâo em Direito pela Universidade Regional do Noroeste do Estado do Rio Grande do Sul (1995). Professora adjunta da Universidade Federal do Rio Grande -FURG, professora do Programa de Mestrado em Direito da Universidade Federal do Rio Grande -FURG. Professora dos cursos de graduaçấo e do Programa de Mestrado em Direito da Faculdade de Direito da Fundaçăo Escola Superior do Ministério Público-FMP. Tem experiência na área de Direito, com ênfase em Teoria Geral do Direito, Direito Constitucional, Direito Ambiental e Direitos Humanos, América latina e questōes decoloniais. Professora pesquisadora do CNPq e FAPERGS. Professora participante do Grupo de Pesquisa em Antropologia Jurídica -GPAJU da UFSC e Pesquisadora do Grupo de Pesquisa Hermenêutica e ciências criminais e Direito e justiça social da Universidade Federal do Rio Grande. Responsável pelo Grupo de Estudos da FURG sobre o Constitucionalismo Latino-Americano.Advogada. Advogada do escritório de Advocacia Luciane Dias Sociedade de Advogados-Pelotas-RS. fabiana7778@hotmail.com

2 Advogado, Mestrando em Direito da Faculdade de Direito da Fundaçâo Escola Superior do Ministério Público - FMP. Advogado. jotaeh@gmail.com 
penitentiary. The methodology is specially based on literature references, that made it possible the theoretical support for the development of the ideas displayed herein. The inductive method was applied for the approach.

KEYWORDS: prison; Woman; Multiculturalism; Segregation.

\section{INTRODUÇÃO}

Em que pesem as discussôes sobre o encarceramento mundial e nacional, notadamente de mulheres, escassos sâo os debates em torno da situaçăo de estrangeiras em situaçăo de privaçăo de liberdade no Brasil. Pelas poucas pesquisas sistemáticas existentes na seara do encarceramento da mulher estrangeira, o presente estudo objetiva demonstrar qual é a relaçăo existente entre os efeitos destrutivos da prisăo e a (im) possibilidade de manutençấo da cultura de origem dessa mulher nos espaços de privaçăo de liberdade.

Mesmo sendo uma minoria, em números absolutos, no sistema penal brasileiro, é preocupante o desrespeito e a negaçáo da cultura da mulher estrangeira quando da sua submissâo ao cumprimento de uma pena privativa de liberdade.

Assim, à luz da questăo de gênero e do multiculturalismo, procura-se abordar o perfil da presa estrangeira, as dificuldades enfrentadas por ela diante da legislaçăo e do sistema prisional pátrios e o quanto as inexistências ou insuficiências de abordagens específicas criam uma série de dificuldades durante o cumprimento da pena.

\section{1. $O$ MULTICULTURALISMO E O PERFIL DA MULHER ESTRANGEIRA EM CUMPRIMENTO DE PENA PRIVATIVA DE LIBERDADE NO BRASIL}

De acordo com Santos e Nunes (2003, p. 26), a concepçăo original do termo multiculturalismo designa a "coexistência de formas culturais ou de grupos caracterizados por culturas diferentes no seio de sociedades modernas". Pode-se afirmar, no entanto, que o multiculturalismo se tornou rapidamente um modo de descrever as diferenças culturais em um contexto transnacional e global. Além disso, afirmam os autores que apesar dessas concepçôes, o multiculturalismo é um termo associado a projetos e conteúdos emancipatórios e contra-hegemônicos, baseados em lutas pelo reconhecimento da diferença.

Nas palavras de Charles Taylor (1997, p. 83), "todas as sociedades estăo a tornar-se cada vez mais multiculturais e, ao mesmo tempo, mais permeáveis. ${ }^{3 \prime}$ Tudo isso conduz à questăo da imposiçấo de algumas culturas sobre outras. E, "considera-se que, neste aspecto, as sociedades liberais do Ocidente săo extremamente culpadas, em parte devido ao passado colonial, em parte devido à marginalizaçâo de segmentos de sua populaçăo oriundos de outras culturas" (TAYLOR, 1997, p. 84).

"A permeabilidade significa que as sociedades estâo mais receptivas à migraçăo multinacional: sâo mais os membros cujo centro se situa noutra parte qualquer, que passaram a conhecer uma vida de diáspora" (TAYLOR, 1997, p. 83). 
Assim a luta multicultural está enraizada no processo histórico de formaçáo dos países americanos, que passaram por um processo de conquista e colonizaçăo, seguido de uma política de assimilaçấo forçada e de eliminaçăo da identidade dos povos ${ }^{4}$ que habitavam as terras "descobertas".

Nesse sentido, o acelerado processo de globalizaçăo que atravessa o mundo, gera novos marcos de regulaçăo e novos cenários que conectam realidades e culturas há muito pouco tempo distantes, mas que acentuam as diferenças sociais e as tensóes étnicas, que fez emergir o multiculturalismo, a interculturalidade e a preocupaçáo com as questōes identitárias e culturais. A questăo multicultural está presente na maioria dos países formados por uma populaçâo heterogênea, por instituiçōes democráticas e atingidos pelas conseqüências desastrosas dos processos de globalizaçăo hegemônica. Esses países apresentam minorias ${ }^{5}$ fortemente discriminadas e exploradas, que carregam o peso da colonizaçấo, da tentativa de assimilaçâo forçada, de incorporaçáo ao cenário nacional e da superioridade de uma cultura dominante, que considera todos os homens como "livres e iguais".

Nesse sentido, segundo os últimos dados do Infopen, do ano de 2014, existem 2.778 presos (dois mil setecentos e setenta e oito) estrangeiros cumprindo pena no Brasil, dos quais $79 \%$ eram homens e $21 \%$ eram mulheres. (BRASIL. Departamento Penitenciário Nacional, 2014, p. 27).

A grande maioria das presas estrangeiras procede da América (318 presas, ou $53 \%$ ), sendo outras 160 da África (27\%), 78 da Europa (13\%), 39 da Ásia (7\%) e 1 da Oceania.

Os dados disponibilizados pelo Infopen do Ministério da Justiça demonstram que os principais países de origem dessas mulheres sāo a Bolívia (99 presas), o Paraguai (83 detentas), a África do Sul (47 segregadas), o Peru (35 presas) e Angola (29 reclusas).

As unidades prisionais do Estado de Sáo Paulo, ao início da pesquisa realizada pelo Ministério de Estado da Justiça (Infopen), nāo disponibilizaram os dados. Porém, os elaboradores do levantamento obtiveram as informaçóes após se valerem da Lei $n^{0}$ 12.527, de 18 de novembro de 2011 (Lei de acesso à informaçáo). Nessa ocasiăo, descobriu-se que no Estado de Sáo Paulo havia 596 mulheres estrangeiras em situaçáo de privaçăo de liberdade. (BRASIL. Departamento Penitenciário Nacional, 2014, p. 28).

\footnotetext{
$4 \quad$ "Pensa-se que desde 1492 os europeus têm vindo a projetar desses povos uma imagem de seres um tanto inferiores, "incivilizados", e que, através da conquista e da força, conseguiram impô-la aos povos colonizados" (TAYLOR, 1997, p, 46).

5 As Naçôes Unidas nâo formalizaram uma definiçâo de minoria universalmente aceita. O primeiro esforço foi desenvolvido pela Sub-Comissâo para Prevençâo da Discriminaçâo e Proteçâo das Minorias, quando, em 1950, sugeria: I - o termo minoria inclui, dentro do conjunto da populaçăo, apenas aqueles grupos nâo dominantes, que possuem e desejam preservar tradiçôes ou características étnicas, religiosas ou lingüísticas estáveis, marcadamente distintas daquelas do resto da populaçấ; II - tais minorias devem propriamente incluir um número de pessoas suficiente em si mesmo para preservar tais tradiçôes e características e - III tais minorias devem ser leais ao Estado dos quais sejam nacionais. Um conceito mais político de minoria é aquele que descreve tais grupos como formado de cidadāos de um Estado, constituindo minoria numérica e em posiçấo nâo-dominante no Estado, dotada de características étnicas, religiosas ou lingüísticas que diferenciam daquelas da maioria da populaçăo, tendo um senso de solidariedade um para com o outro, motivado, senáo apenas implicitamente, por uma vontade coletiva de sobreviver e cujo objetivo é conquistar igualdade com a maioria, nos fatos e na lei. Novamente estăo presentes critérios objetivos e subjetivos, além da introduçấo de elemento político: nacionalidade ou cidadania do Estado (SÉGUIN, 2002. p. 9).
} 


\section{A PRISÃO COMO ESPAÇO DE NEGAÇÃO DO MULTICULTURALISMO}

Do conjunto de pessoas que compóem a massa carcerária, a mulher năo tem destaque. No Brasil, o percentual de mulheres estrangeiras presas gira em torno de $2 \%$. (BRASIL. Departamento Penitenciário Nacional, 2014, p. 29).

Michael Mary Nolan, da Pastoral Carcerária da Igreja Católica e também Presidente do Instituto Terra Trabalho e Cidadania (ITTC), com sede em Sáo Paulo, com olhos postos nas presas estrangeiras, relata que a criminalidade feminina temse voltado para os crimes de tráfico de entorpecentes, nos quais a mulher é utilizada como o que vulgarmente se conhece como sendo uma "mula" do tráfico, vale dizer, uma pequena traficante/transportadora/possuidora de drogas para a venda internacional. (FONTELES, 2014).

Olga Espinoza (2002, p. 36), pesquisadora do Centro de Estudios en Seguridad Ciudadana da Universidade do Chile, explica que, quando se trata de mulher e de seu envolvimento com o sistema punitivo, parte-se da ideia de que o sistema criminal está em crise, pois à medida que esse sistema năo cumpre minimamente as suas funçôes, entre elas as de proteçăo ao bem jurídico e de prevençấo de determinadas condutas, ele (sistema) se mostra como uma entidade seletiva - o sistema selecionará quem punir para ulterior criminalizaçăo e vitimizaçăo, tendo como principal cliente os miseráveis.

Referida autora aduz que "a perversidade do sistema criminal se estabelece através do 'aparato de publicidade' do Estado, que projeta a ilusăo de um poder punitivo igualitário, náo seletivo, náo discriminador, disfarçando de conjuntural ou circunstancial aquilo que é estrutural e permanente (inerente ao próprio poder)". (ESPINOZA, 2002, p. 37).

Assim, no universo intramuros, a prisăo é um lugar frio, triste, representado, como lembra Julita Lemgruber, por uma caricatura da sociedade em si, haja vista ser um ambiente que reforça a exclusăo das mulheres segundo as condiçôes já vividas anteriormente, sem prejuízo da intensificaçăo dos males que causa, isso quando năo as infantiliza e as faz depender de uma autoridade externa (os agentes do Estado) para, logo em seguida, buscar que tenham maturidade para que sejam declaradas ressocializadas. (LEMGRUBER, 1999, p. 45).

Sob este enfoque, pode-se pensar, como Manuela Ivone P. Pereira da Cunha, antropóloga da Universidade do Minho, em superaçăo do tradicional conceito de Ervin Goffman no sentido de que a prisăo é uma "instituiçăo total" (CUNHA, 2004), pois o espaço intramuros náo parece ser muito distinto daquela da sociedade livre, mormente de alguns anos para cá, quando os cárceres se tornaram mais "porosos", isto é, mais abertos a vários setores sociais, como a imprensa, os operadores do direito, organizaçôes sociais (igrejas, conselhos de comunidade) e assim por diante.

É cediço, no entanto, que a prisáo surgiu como sucedâneo da pena de morte, apesar de já ter sido concebida de modo falho. Diante disso, a prisăo tornou-se uma instituiçăo dotada de características que lhe sâo muito peculiares, de tal modo que o seu sistema de funcionamento interno, por mais permeável que seja ao controle social, ainda guarda características que lhe săo próprias.

Nesse particular, quando se fala em encarceramento feminino o primeiro passo foi o de separar os homens das mulheres, dando a elas um tratamento pretensamente 
distinto. Assim, no seu (ir) regular desenvolvimento, a instituiçăo da prisâo adquiriu qualidades e contornos tipicamente masculinos, relegando o sexo feminino a uma conjuntura de invisibilidade, ainda mais quando passou a desrespeitar ou, quando menos, a năo-observar as características, diferenças e necessidades que a mulher possui quando está a cumprir pena.

Diante desse cenário, a massa carcerária feminina obrigou-se ao longo dos anos a se adaptar a padróes masculinos de aprisionamento, ferindo de morte seus direitos enquanto mulheres presas, resultado de uma cultura institucional patriarcal, que pode ser vista, de início, na arquitetura e na infraestrutura das penitenciárias femininas, isso quando nâo sâo, simplesmente, construídos anexos aos cárceres masculinos, realizando-se uma simples adaptaçâo destes às necessidades daquele determinado espaço, que de um momento para outro passa a alojar mulheres.

Desse modo, além de serem espaços de privaçăo superlotados, sem condiçôes de salubridade para os internos, excesso de presos provisórios, o problema se agrava ainda mais quando se trata de mulher estrangeira em cumprimento de pena.

Nesse contexto de negaçăo de direitos, os aspectos culturais săo constantemente violados, pois a indiferenciaçấo forçada do cárcere nâo respeita as peculiaridades de cada apenada, tais como origem, língua, religiăo, forma de vestir e assim por diante. A prisáo impóe, assim, uma cultura comum a todas as presas.

Há uma multiplicidade de aspectos que a prisáo de mulheres, em especial a de estrangeiras, acaba por vulnerar. Nesse sentido, alguns deles săo bastante visíveis e perceptíveis, a começar pelo problema da língua e da falta de informaçâo sobre os seus mais elementares direitos enquanto presa.

\subsection{0 problema da barreira do idioma e da falta de comunicaçáo}

Embora nâo seja previsto como direito expresso na Lei de Execuçăo Penal (LEP Lei 7.210/84), a traduçăo de peças do processo penal e do de execuçáo penal para o idioma natal é prevista na Convençáo Americana sobre Direitos Humanos, também denominado de Pacto de San Jose da Costa Rica. Este tratado, em seu art. 8-, nº 2, alínea "a", prevê que entre as garantias judiciais do preso estrangeiro está o de o "[...] acusado de ser assistido gratuitamente por tradutor ou intérprete, se náo compreender ou nâo falar o idioma do juízo ou tribunal".

Igualmente, o Decreto n 592/1992, que internalizou no ordenamento jurídico brasileiro o Pacto Internacional sobre Direitos Civis e Políticos (adotado pela XXI Sessáo da Assembleia-Geral das Naçôes Unidas, em 16 de dezembro de 1966), dispōe que toda a pessoa acusada de um delito terá direito, em plena igualdade, a garantia de "a) ser informado, sem demora, numa língua que compreenda e de forma minuciosa, da natureza e dos motivos da acusaçăo contra ela formulada." (art. 14, § 3º, alínea a).

Nâo obstante tais preceitos sejam aplicáveis, em tese, ao processo de conhecimento, tais garantias sáo, por óbvio, extensíveis à execuçâo penal, uma vez que se trata de um processo judicialiforme, misto de atividade jurisdicional e administrativa. Afinal, conhecer direitos em um contexto de encarceramento em uma cultura diferenciada é fundamental para possibilitar o seu exercício. Se a comunicaçâo é truncada ou nâo é viabilizada, faltará à presa a necessária compreensăo de como funciona o complexo 
sistema de justiça criminal brasileiro, de forma que os aspectos culturais acabam sendo negados ou completamente amesquinhados.

Um exemplo desse cipoal jurídico-processual que muitas vezes baralha e causa perplexidade a presos (as) estrangeiros (as), nomeadamente aqueles (as) condenados (as) por tráfico internacional de drogas pela Justiça Comum Federal, tem-se no fato de que o seu recurso de apelaçăo será apreciado, enquanto a execuçâo penal tiver caráter provisório, pelo respectivo Tribunal Regional Federal. Paralelamente, a execuçăo provisória, por força do que dispōe a súmula 192 do Superior Tribunal de Justiça, conjugada com os ditames da Resoluçấo CNJ 113/2010, já pode estar tramitando no juízo estadual, que, se negar algum direito a esse (a) preso (a) estrangeiro (a) (v.g., a progressăo de regime) ensejará o aviamento de recurso de agravo em execuçâo (LEP, art. 197), que será julgado por um tribunal estadual.

Outro exemplo desse confuso sistema jurídico processual é encontrável em entrevista dada ao site de notícias G1.com, em 24 de outubro de 2010, por Heidi Ann Cerneka, entáo vice-coordenadora nacional da Pastoral Carcerária, que vaticinou que há "[...] presos que falam um pouco de inglês e espanhol e isso facilita a comunicaçâo. Mas tivemos uma chinesa presa com documentos falsos que ficou muda por três meses, até que a Pastoral conseguiu alguém que pudesse ajudá-la."(DUARTE, 2010).

Essa complexa situaçăo demonstra como é difícil explicar a um preso alienígena os caminhos tortuosos do processo penal brasileiro, até mesmo na fase de execuçāo da pena.

Nesse aspecto, interessante notar as recentes Regras de Mandela, de outubro de 2015 (Regras 54 e 55), que reforçam a necessidade de traduçăo de documentos também na seara da execuçăo para que o/a presa/a estrangeiro/a tenha conhecimento sobre a legislaçăo e os regulamentos concernentes à unidade prisional e ao sistema prisional em que está recolhido, nomeadamente com a disponibilizaçăo de tais regras nos principais idiomas utilizados, de acordo as necessidades da populaçăo prisional. (BRASIL. Conselho Nacional de Justiça, 2016b, p. 30).

\subsection{Religiăo}

A liberdade de crença é assegurada pela CF em seu art. $5^{\circ}$, inciso VI. De seu lado, a LEP, como derivaçăo dessa garantia constitucional, estabelece como direito da presa a assistência religiosa.

Todavia, nas prisóes brasileiras as mulheres, na sua maior parte, săo atendidas pela Pastoral Carcerária ou pelas Igrejas evangélicas. Esse cenário se torna mais difícil e complexo quando se têm presas que professam crenças năo cristăs, entre elas aquelas de matriz africana e as muçulmanas, que dificilmente terăo garantido o seu direito de liberdade de crença no interior de uma penitenciária feminina. A padronizaçáo de tratamento penal, que năo respeita as diferenças religiosas, torna muito difícil - se năo impossível - o exercício dessa liberdade no contexto do cumprimento da pena corporal.

Nesse norte, a reportagem acima citada identificou já naquela época "um grupo de muçulmanas que, para manter suas tradiçōes, tentam conseguir refeiçóes diferentes e horários para rezar." (DUARTE, 2010). 
Isso sem falar em outras dificuldades que daí advêm para as que professam essa mesma fé, como, p. ex., a de jejuar durante o dia no período do Ramadâ. Complica náo apenas o exercício da garantia da crença, mas tumultua a própria rotina da organizaçâo penitenciária, que năo é preparada ou capacitada para essas vicissitudes, em especial quando presas estrangeiras e brasileiras cumprem pena em um mesmo estabelecimento penal, contrariando a Regra 65, item 1 das vigentes Regras de Mandela. (BRASIL. Conselho Nacional de Justiça, 2016b, p. 32).

\subsection{Acompanhamento jurídico}

Falta a boa parte das presas estrangeiras acompanhamento jurídico especializado por parte do Estado, como determina o art. 15 da LEP. A assistência jurídica, sobretudo com o trabalho que deveria ser desenvolvido mais eficazmente pelas Defensorias Públicas da Uniâo e dos Estados, ainda é muito incipiente e necessita de vários aperfeiçoamentos, resultando na total desinformaçăo ou parca informaçăo sobre como estâo a tramitar seus pleitos, seus processos e sua situaçăo jurídica, malferindo a Regra 119, itens 1 e 2 das Regras de Mandela. (BRASIL. Conselho Nacional de Justiça, 2016b, p. 43).

Nesse particular, André Luiz de Almeida e Cunha, ex-Diretor de Políticas Penitenciárias do Departamento Penitenciário Nacional (DEPEN), à época da reportagem, ressaltou que, ao receber um estrangeiro, o sistema informa ao consulado do país de origem da presa para fornecer a assistência jurídica a que ela faz jus. Todavia, "o problema é que alguns consulados năo se manifestam e năo fazem contato com a família do preso. Dessa forma é mais difícil o apoio de um advogado enviado por parentes para se comunicar com o apenado". (DUARTE, 2010).

Esse quadro se torna especialmente sensível se entre o Brasil e o país de origem da presa nâo existe qualquer tratado bi/multilateral acerca do cumprimento da pena.

\subsection{Visita íntima e de familiares}

Sob outro viés, quanto à visita íntima, a mulher sofre seguidamente com a ausência de seu marido/companheiro, que em boa parte dos casos a abandona durante o cumprimento da pena.

As mulheres também sofrem com os casos de "homossexualismo imposto", notadamente a partir de carências afetivas e da real ausência de liberdade para decidir sobre a escolha de seu par.

Por outro lado, no caso das presas estrangeiras, sentem elas a falta de contato e do apoio da família, que se encontra em outro país.

Segundo o Ministério da Justiça, o Brasil possui 12 (doze) Tratados Bilaterais de Transferência de Pessoas Condenadas, em vigor, e 3 (três) multilaterais, a saber:

Angola: Celebrado em 03.05.2005 e promulgado pelo Decreto n 8.316, de 24.09.2014. Argentina: Celebrado em 11.09.1998 e promulgado pelo Decreto $n^{\circ} 3.875$, de 23.07.2001.

Bolívia:Celebrado em 26.07.2007 e promulgado pelo Decreto n 6.128, de 20.06.2007.

Canadá: Celebrado em 15.07.1992 e promulgado pelo Decreto $n^{\circ} 2.547$, de 14.04.1998. 
Chile: Celebrado em 29.04.1998 e promulgado pelo Decreto n 3.002, de 26.03.1999.

Convençâo Interamericana sobre o Cumprimento de Sentenças Penais no Exterior: Celebrado em 26.07.2007 e promulgado pelo Decreto nº 6.128, de 20.06.2007. Países signatários: Arábia Saudita, Belize, Brasil, Canadá, Chile, Costa Rica, El salvador, Equador, Estados Unidos, Guatemala, México, Nicarágua, Panamá, Paraguai, República Tcheca, Uruguai e Venezuela.

Convençăo sobre a Transferência de Pessoas Condenadas entre os Estados Membros da Comunidade dos Países de Língua Portuguesa (CPLP): Celebrado em 23..11.2005 e promulgado pelo Decreto no 8.049, de 11.07.2013. Países: Angola, Brasil, Cabo Verde, Guiné Bissau, Moçambique, Portugal, Săo Tomé e Príncipe, Timor Leste.

Espanha: Celebrado em 04.05.1998 e promulgado pelo Decreto $n^{0} 2.576$, de 30.04.1998.

Mercosul: Acordo sobre Transferência de Pessoas Condenadas entre os Estados Partes do Mercosul, celebrado em 16.12.2004 e Promulgado pelo Decreto nº 8.315, de 24.09.2014.

Panamá: Celebrado em 10.08.2007 e promulgado pelo Decreto $n^{\circ}$ 8.050, de 11.07.2013

Paraguai: Celebrado em 29.10.2002 e promulgado pelo Decreto $n^{\circ} 4.443$, de 28.10.2002.

Peru: Celebrado em 25.08.2003 e promulgado pelo Decreto n 5.931, de 13.10.2006.

Portugal: Celebrado em 25.08.2007 e promulgado pelo Decreto $n^{0}$ 5.767, de 02.05.2006.

Reino dos Países Baixos: Celebrado em 23.01.2009 e promulgado pelo Decreto n ${ }^{\circ}$ 7.906 de 04.02.2013.

Reino Unido da Grä-Bretanha e Irlanda do Norte: Celebrado em 29.01.2002 e promulgado pelo Decreto $n^{\circ}$ 4.107, de 28.01.2002. (BRASIL. Justiça e Cidadania, 2016).

A despeito desses tratados e da Regra 58, itens 11 e 2, das Regras de Mandela, ainda há uma distância entre o que pretendem garantir esses pactos e a dura realidade das presas estrangeiras no Brasil. (BRASIL. Conselho Nacional de Justiça, 2016b, p. 31).

\subsection{Trabalho}

O trabalho das presas é assegurando pelos arts. 28 a 30 da LEP, sem prejuízo do que dispóem as atuais Regras de Mandela, 4, item 2, 95 a 103 (BRASIL. Conselho Nacional de Justiça, 2016b). Porém, no caso das mulheres, o trabalho que é disponibilizado pelo Estado é, geralmente, sujeito a padrôes de formaçăo e capacitaçấo tidos como "apropriados" e "tipicamente femininos", como os ofícios de cabeleireira, manicure, cozinheira, treinamento para a realizaçăo de serviços domésticos em geral.

Mesmos nesses casos, o trabalho prisional da estrangeira em cumprimento de pena ainda encontra barreiras, dada a disposiçăo do art. 98 da Lei 6.815, de 19 de agosto de 1980 (Estatuto do Estrangeiro), que trata do estrangeiro submetido a processo de expulsăo.

Esse diploma foi invocado como uma das razóes de decidir pela entăo Ministra Ellen Gracie para náo conceder a ordem de Habeas Corpus n 97.147/MT. Na ocasiǎo, a Ministra foi acompanhada pelos Ministros Eros Grau e Joaquim Barbosa. 
Todavia, após pedido de vista do Ministro Peluso, este divergiu do voto da MinistraRelatora e, em síntese, fundamentou sua decisâo nos papéis que o trabalho prisional exerce - ou deveria exercer - na execuçăo penal, bem como pelo fato de o decreto de expulsăo, quando já emitido pelo Ministro de Estado da Justiça, gerar um tratamento discriminatório

[...] no exercício de direitos relacionados com a execuçăo de sua pena privativa de liberdade, isto é, ao gozo do livramento condicional, da progressăo de regime prisional, da suspensáo condicional da pena, dentre outros instrumentos jurídicos pertinentes. (BRASIL, Supremo Tribunal Federal, 2009).

O CNJ, durante a realizaçâo dos mutirôes carcerários de 2009 a 2013, realizou visitas e inspeçôes em todas as unidades da federaçấo e constatou como săo escassas as ofertas de trabalhos no meio prisional, seja para homens, seja para mulheres. As observaçóes contidas nos relatórios das diversas unidades da federaçâo visitadas mostram que o Estado é o maior omisso em procurar ofertar trabalho aos (às) presos(as) de forma sistemática, de modo que o que predomina na maior parte das prisóes brasileiras é o ócio. (BRASIL, Conselho Nacional de Justiça, 2016).

Respeitante às presas estrangeiras, essas dificuldades mais se fazem notar pela dificuldade de idioma, diversidade cultural e quando progridem elas para os regimes semiaberto e aberto, ou obtém o livramento condicional, dificilmente conseguem ocupaçâo lícita, quer porque nâo possuem cédula de identidade para estrangeiro, seja porque náo conseguem obter a Carteira de Trabalho e Previdência Social (CTPS), justamente pela sua própria condiçấo de estrangeiras a cumprir pena privativa de liberdade, năo possuírem residência no Brasil, somando-se a tudo isso a circunstância de que paralelamente à execuçăo da pena ainda tramita o processo administrativo destinado a expulsá-la do país em virtude do cometimento do crime em território nacional.

\subsection{Documentaçăo}

Os problemas para a obtençáo de emprego residem nas dificuldades da obtençâo da documentaçâo para sua permanência legal no Brasil, antes de ultimado o processo de expulsâo previsto no Estatuto do Estrangeiro.

Nesse sentido, alguns juízes federais ao longo do tempo vêm reconhecendo a possibilidade de que presos (as) estrangeiros (as), ainda em cumprimento de pena, obtenham a CTPS para que assim trabalhem licitamente em território brasileiro.

Exemplo disso ocorreu em Campinas, por decisāo do Juízo da 24ª Vara Federal, que determinou a expediçăo de CTPS em prol de uma senegalesa condenada por tráfico internacional de drogas. Na ocasiăo, o magistrado ressaltou que "o princípio da igualdade deve ser observado com o fim de assegurar ao estrangeiro uma forma digna de cumprimento de pena e assegurando-lhe todas as garantias, pois sua condiçăo jurídica nâo o desqualifica como sujeito de direitos". (ANGELOTTO JUNIOR, 2014).

Nessa linha, procurando suprir essa lacuna e de certa forma dando uma interpretaçăo mais atualizada ao Estatuto do Estrangeiro, sobretudo em funçăo do aumento do encarceramento de estrangeiros no Brasil, o Conselho Nacional de Imigraçăo (CNImg) editou a Resoluçáo Normativa n 110, de 10 de abril de 2014, pela qual autorizou a "concessâo de permanência de caráter provisório, a título especial, com fins a estabelecimento 
de igualdade de condiçóes para cumprimento de penas por estrangeiros no Território Nacional. " (BRASIL. Conselho Nacional de Imigraçăo, 2014).

Posteriormente, o Ministério da Justiça regulamentou a Resoluçăo do CNImg por meio da Resoluçấo n 06, de 30 de janeiro de 2015, que autorizou a "concessấo de permanência de caráter provisório, a título especial, a estrangeiros que sejam réus em processos criminais ou estejam cumprindo pena no Território Nacional." (BRASIL. Secretaria Nacional de Justiça, 2015).

Essas iniciativas procuraram se ajustar aos preceitos inscritos nas Regras 107 e 108 das Regras de Mandela. (BRASIL. Conselho Nacional de Justiça, 2016b, p. 41).

\subsection{Maternidade}

O contato de presas estrangeiras com os filhos fica inviabilizado pela segregaçâo em território brasileiro. Muito raramente os filhos de presas estrangeiras têm condiçōes de vir ao Brasil para visitar suas măes ou parentes no cárcere, até mesmo porque a maioria das presas é de estrato social pobre em seus países de origem.

Andrea Dip (2014), baseada em trabalho desenvolvido pelo Instituto Terra Trabalho e Cidadania (ITTC), registra que as presas estrangeiras nâo têm com quem deixar os bebês, quando sâo presas já grávidas, pelo fato de o contato familiar ser complexo e a família năo ter dinheiro para buscar essa criança estrangeira em cumprimento de pena", de sorte que a presa se vê obrigada a entregar seu filho para o abrigo.

A falta de contato dessa mulher presa com sua prole ocasiona a ruptura dos vínculos familiares, gerando transtornos psicológicos à măe e à criança, o que desatende năo apenas aos interesses da segregada, mas viola também e de modo muito especial os superiores interesses da criança, violando o comando do art. 227 da Constituiçấo Federal e a Regra 106 das Regras de Mandela. (BRASIL. Conselho Nacional de Justiça, 2016b, p. 41).

Por outro lado, procurando minorar as consequências do encarceramento feminino, em especial da presa gestante, a Lei $n^{\circ} 12.403$, de 04 de maio de 2011, incialmente estabeleceu a possibilidade de concessâo da prisâo domiciliar a partir do sétimo mês para presas provisórias. Posteriormente, a Lei nº 13.257 de 08 de março de 2016, alterou a lei para contemplar simplesmente a presa gestante, independentemente da fase gestacional.

Embora, a legislaçâo brasileira nâo retire a presa estrangeira do campo de sua aplicaçăo, a possibilidade da prisâo domiciliar nesses casos é praticamente nula, justamente porque ela năo possui domicílio em território nacional. A alternativa que se coloca é a de acolhimento das crianças e das mâes em instituiçôes públicas ou privadas que concordem em recebê-las nesse período, o que dependente em muito da boa vontade do Estado-Juiz, das parcas estruturas do Estado-administraçăo e da receptividade de $O N G$ 's que se dedicam à matéria.

O que se vê, portanto, é que, embora năo se tenha inventado nada mais evoluído que a pena de prisáo para aquelas pessoas que cometeram delitos considerados mais graves, de modo que devem elas cumprir a imposiçăo que resulta da sentença penal condenatória, vive-se quadro de completa afronta aos mais comezinhos direitos da pessoa privada de liberdade - aqui, com destaque, para as mulheres estrangeiras -, a saber, o direito à integridade física e mental, educaçăo, saúde, trabalho. 
A reportagem do site de notícias G1, do ano de 2010, há pouco trazida à colaçăo, reafirma o que foi dito no levantamento do Infopen realizado em 2014. Em 2010 já se vaticinava que:

Destacam-se como problemas comumente vivenciados por pessoas estrangeiras presas: a dificuldade de obtençáo de livramento condicional e de progressáo de regime, dada a maior dificuldade dessas pessoas em atender às condiçóes exigidas pela Lei de Execuçăo Penal (como a obtençăo de ocupaçăo lícita, dentro de prazo razoável); a dificuldade em receber visitaçáo e manter contato com a família; a carência à assistência consular; as dificuldades relacionadas à barreira linguística, como a falta de acompanhamento jurídico; o desconhecimento das regras disciplinares e do processo de execuçâo penal. (BRASIL. Departamento Penitenciário Nacional, 2014).

Nessa trilha, o multiculturalismo, conforme leciona Andrew Heywood (2010, p.95), caracteriza-se por

[...] um firme apoio à diversidade no interior da comunidade, tomando como base o direito de diversos grupos culturais ao reconhecimento e ao respeito. Nesse sentido, o multiculturalismo reconhece como as crenças, os valores e os estilos de vida sáo importantes para que os indivíduos ou grupos desenvolvam o respeito por si próprios. Culturas diferentes merecem ser protegidas e fortalecidas, principalmente quando pertencem a grupo minoritários ou vulneráveis. Existem, porém, vários modelos conflitantes de sociedade multicultural que se baseiam, de maneiras variadas, nas ideias do liberalismo, do pluralismo e do cosmopolitismo.

Assim, se o multiculturalismo prevê o respeito à diversidade, a prisăo, por seu turno, aniquila essa possibilidade na exata medida em que procura sempre homogeneizar comportamentos e expectativas de condutas. Essa última percepçăo é própria do que se denomina multiculturalismo conservador, que é aquele que, em síntese: "reconhece a possibilidade de que haja outras culturas, porém nâo realiza um esforço para que as mesmas sejam culturalmente valorizadas." (GANDIN; HYPOLITO, 2003, p. 7).

O sistema de justiça criminal, em especial na fase de execuçăo penal, procura dar um aparente tratamento isonômico às condenadas e por aí, desde logo, acaba por consagrar violaçóes no que tange às identidades pessoais e culturais das sentenciadas, embora a CF e a LEP assegurem a individualizaçăo da pena como princípio a ser sempre observado. Em realidade, tem-se mais um discurso formal de garantias de direitos, que năo encontra eco na realidade cotidiana. O que se tem, ao fim e ao cabo, sâo tremendas desigualdades e profundas dissintonias entre os enunciados constitucionais e legais e a realidade do cárcere.

Pode-se aqui, ainda, raciocinar de maneira bastante abrangente para trazer à tona um aspecto que, para as presas estrangeiras, adquire um caráter ainda mais dramático, qual seja, a questâo da passagem do tempo na prisâo em um país estranho a partir dos ensinamentos de Ana Messuti, citada por María Soledad Carrozza.

Nessa direçăo, Ana Messuti (2008, p. 29-30) tem tentado compreender a prisăo a partir da noçăo de tempo. Segundo Messuti:

[...] así como hay una ruptura en el espacio señalada los muros de la prisión, también hay uma ruptura en el tiempo. La pena de prisión se diferencia de toda otra pena por la forma en que combina estos dos elementos: el tiempo y el espacio. Esta 
intersección entre tiempo y espacio marca el comienzo de una duración distinta, cualitativamente diversa. Y ello a pesar de que la pena se mide con la misma unidad que se utiliza para medir el tiempo social, el tiempo común.

María Soledad Carroza, lastreada em Ana Messuti, assinala que essa autora distingue duas qualidades do tempo: o tempo social ou comum, que transcorre num espaço social, fora das fronteiras que constrói a prisăo, e um tempo da pena, que lhe é próprio, que a constitui e para a qual se identifica uma duraçăo distinta. Esta diferença năo é cronológica, năo reside em sua extensâo, senăo em sua qualidade, na intensidade com que ela é vivida.

Para Ana Messuti (2008, p. 34-35):

Al construyrse la prisión se pretende inmovibilizar el tiempo de la pena. Separarlo del tiempo social que transcurre en el espacio social. La prisión es una construcción en el espacio para calcular de determinada manera el tiempo. Al fluir del tiempo e opone la firmeza del espacio. El orden jurídico, mediante la prisión, intenta dominar el tiempo. Parecería que el tiempo en el que transcurre la vida social normal fuese un tiempo relativo, y que el tiempo de la pena, transcurre en la prisíón, asumiera un carácter absoluto.

Postas essas consideraçóes, percebe-se claramente que o transcurso do tempo na prisăo para uma presa nacional já é objeto de toda sorte de temores e angústias. Isso mais se intensifica para a presa estrangeira, para qual o tempo de aprisionamento em território estrangeiro parece uma eternidade.

Por isso é que Olga Espinoza (2002, p. 52) reforça o sentido de que a prisāo é "uma instituiçâo totalizante e despersonalizadora, na qual a violência se converte em um instrumento de troca, em que prevalece a desconfiança e o único objetivo das pessoas é sair, fugir, atingir a liberdade".

Nessa linha de raciocínio, as Regra de Mandela, em especial as regras de aplicaçăo geral (Regra; 2, itens 1 e 2) tem o objetivo de fazer observar as diversidades culturais, para além de afirmar o conceito de multiculturalismo, servindo decisivamente para atenuar as agruras do cárcere, pois aproximariam a presa estrangeira de vivências e aspectos que lhe săo mais próximos.

\section{A LEGISLAÇÃO DE REGÊNCIA E VISÃO DE FUTURO}

Como citado, alguns diplomas legais contemplam as particularidades de mulheres no cumprimento da pena em seus aspectos multiculturais, que văo desde a questâo do problema do idioma chegando até a questăo da maternidade. Porém, ainda há uma distância muito grande entre o plano normativo e a realidade enfrentada pelas mulheres presas, nomeadamente as estrangeiras.

Nesse diapasăo, a recente traduçăo das regras de Bangkok pelo CNJ foi importante passo no Brasil para diminuir a distância entre os enunciados legais e a dura realidade vivida pelas presas, em especial as estrangeiras. (ZAMPIER, 2016).

Porém, o Judiciário brasileiro já havia se adiantado, em parte, ao editar a Resoluçâo CNJ de $n^{0} 162$, de 13 de novembro de 2012, que impôs aos juízes brasileiros a necessidade, por ocasiăo da prisấo, de comunicar a representaçăo diplomática do país de origem da mulher estrangeira ou ao Ministério das Relaçôes Exteriores - na hipótese 
de inexistência de representaçăo diplomática no Brasil - com o intuito de fazer com que os representantes diplomáticos passem a assistir o seu nacional quando preso no Brasil, facilitando aspetos como traduçấo de documentos, contatos com os familiares no exterior e apoio para o cumprimento de eventual pena.

A Resoluçâo em comento estimulou a criaçăo de um cadastro de presos estrangeiros pelo Ministério da Justiça para fazer transitar as informaçôes entre este órgão e o Poder Judiciário brasileiro, com vistas a agilizar o processo de expulsăo previsto no Estatuto do Estrangeiro ou, ao menos, possibilitar a aplicaçâo de tratados bi/multilaterais para o cumprimento da pena imposta no Brasil no país de origem.

Outro louvável projeto do CNJ foi a ediçâo, em 2011, da "Cartilha da Mulher Presa" em português, inglês e espanhol, visando a informar as presas nacionais e estrangeiras sobre os seus direitos na órbita da execuçăo penal.

Interessante inciativa foi também adotada pela Secretária de Administraçăo Penitenciária (SAP) do Estado de Sáo Paulo, que entendeu por bem reunir os presos estrangeiros homens em único estabelecimento prisional (em Itaí, interior do Estado) e, no caso das mulheres, na Penitenciária Feminina da Capital (PFC), o que facilita a aplicaçăo e observância de diferentes aspectos jurídicos e culturais que envolvem o respectivo cumprimento de pena. (SĂO PAULO. Secretaria de Administraçăo Penitenciária, 2016).

A concentraçăo de presas estrangeiras numa só unidade facilita o trabalho de reinserçâo e procura garantir a especializaçâo de servidores penitenciários e dos demais dispositivos do sistema de justiça para esse particular público que cumpre a pena no Brasil.

Atualmente, as Regras de Mandela, que atualizaram as Regras de Tóquio de 1955, preveem no item 621 que "Presos estrangeiros devem ter acesso a recursos razoáveis para se comunicarem com os representantes diplomáticos e consulares do Estado ao qual pertencem. 2. Presos originários de Estados sem representaçăo diplomática ou consular no país e refugiados ou apátridas devem ter acesso a recursos similares para se comunicarem com os representantes diplomáticos do Estado encarregados de seus interesses ou com qualquer autoridade nacional ou internacional que tenha como tarefa proteger tais indivíduos." (BRASIL. Conselho Nacional de Justiça, 2016b, p. 32).

Como se pode observar em linhas anteriores, năo é a ausência de tratados internacionais ou de legislaçáo nacional que nâo permite ou inviabiliza o cumprimento da pena e a necessidade de observaçâo dos vários aspectos multiculturais nela envolvidos. O que existe, repise-se, é uma distância entre os parâmetros normativos e a realidade de cumprimento de penas nos cárceres nacionais por estrangeiras.

Sem dúvida alguma, a concretizaçăo dos direitos passa por sensibilizaçấo e por instar as autoridades administrativas a tornarem efetivas as particularidades que decorrem das diferenças. Do contrário, os direitos acima elencados serâo sempre diretivas gerais e abstratas que dificilmente alcançaráo concretude e imporăo mudanças nas rotinas penitenciárias.

Talvez, o início disso tudo isso seja resgatar a individualizaçăo da pena prevista na CF e na LEP para todas as presas (nacionais e estrangeiras), pelo trabalho realizado pela Comissăo Técnica de Classificaçăo (CTC), que năo deve ser uma simples norma programática despida de conteúdo eficaz. 
Ainda que isso năo seja plenamente possível, como prescreve e exige o art. $8^{\circ}$ da LEP, poder-se-ia trabalhar a questáo do encarceramento de presas estrangeiras a partir de suas origens geográficas e das suas múltiplas culturas. Nesse quadrante, o trabalho reunindo grupos específicos, ainda que numericamente năo muito expressivos, parece ser um bom caminho a seguir.

\section{CONSIDERAÇÕES FINAIS}

Como se viu ao longo do trabalho, os espaços de privaçáo de liberdade sâo espaços de negaçăo de aspectos multiculturais.

Há para a mulher, pela sua simples condiçăo, uma sobrepena, porque geralmente é afastada da família e do convívio dos filhos, situaçăo que se agrava com as presas estrangeiras.

No Brasil deve-se fazer um intenso trabalho no sentido de afirmar a prevalência de tratados internacionais e a CF que asseguram os direitos das mulheres, e em especial, para as presas estrangeiras. Do contrário, o discurso jurídico continuará distante da prática e será pouco efetivo.

Em que pese tal cenário, já se notam açôes inclusivas no sentido de romper com essa lógica de exclusâo e negaçăo de aspectos multiculturais, seja por iniciativa do CNJ, seja por iniciativa de algumas Secretárias de Administraçăo Penitenciária das unidades da federaçăo, procurando dar as condiçôes de possibilidade da aplicaçăo das Regras de Mandela, aprovadas pela ONU em outubro de 2015.

Certamente, quanto menos despersonificante for a execuçâo da pena e mais observadora das diversidades culturais for o seu cumprimento, mais sucesso se terá na reinserçâo social da apenada, que voltará ao seu país da melhor forma possível. 


\section{REFERÊNCIAS BIBLIOGRÁFICAS}

ANGELOTTO JUNIOR, Sergio. Presa estrangeira consegue autorizaçăo judicial para tirar a Carteira de Trabalho no Brasil. JusBrasil, Brasília, 2014. Disponível em: <http://angelotto.jusbrasil.com.br/noticias/147722339/presa-estrangeira-consegue-autorizacaojudicial-para-tirar-a-carteira-de-trabalho-no-brasil>. Acesso em: 12 out. 2016.

BRASIL. Conselho Nacional de Imigraçăo. Resoluçăo Normativa CNIg n 110, de 10 de abril de 2014. Autoriza a concessâo de permanência de caráter provisório, a título especial, com fins a estabelecimento de igualdade de condiçōes para cumprimento de penas por estrangeiros no Território Nacional. Disponível em: <https://www.legisweb.com.br/ legislacao/?id=269310>. Acesso em: 12 out. 2016.

BRASIL. Conselho Nacional de Justiça. Mutirăo carcerário: Relatórios. Brasília, 2016a. Disponível em: <http://www.cnj.jus.br/sistema-carcerario-e-execucao-penal/pj-mutirao-carcerario/relatorios>. Acesso em: 12 out. 2016.

BRASIL. Conselho Nacional de Justiça. Regras de Mandela: Regras mínimas das Naçóes Unidas para o tratamento de presos. Brasília, 2016a. Disponível em: <http://www.cnj. jus.br/files/conteudo/arquivo/2016/05/39ae8bd2085fdbc4a1b02fa6e3944ba2.pdf>. Acesso. 13 out. 2016.

BRASIL. Conselho Nacional de Justiça. Resoluçăo nº 162, de 13 de novembro de 2013. Dispóe sobre a comunicaçáo de prisâo estrangeiro à missấo diplomática de seu respectivo Estado de Origem. Disponível em: <http://www.cnj.jus.br/files/atos_administrativos/ resoluo-n162-13-11-2012-presidncia.pdf>. Acesso em: 12 out. 2016.

BRASIL. Departamento Penitenciário Nacional. Levantamento nacional de informaçôes penitenciárias: INFOPEN Mulheres. Brasília, DF: Ministério da Justiça, jun. 2014. Disponível em: <http://www.justica.gov.br/noticias/estudo-traca-perfil-da-populacao -penitenciaria-feminina-no-brasil/relatorio-infopen-mulheres.pdf>. Acesso em: 10 out. 2016.

BRASIL. Justiça e Cidadania. Cooperaçăo internacional: transferência de pessoas condenadas. Brasília, DF, 2016. Disponível em: 〈http://www.justica.gov.br/seus-direitos/ estrangeiros/cooperacao-internacional/transferencia-de-pessoas-condenadas>. Acesso em: 12 out. 2016.

BRASIL. Secretaria Nacional de Justiça. Portaria nº 6, de 30 de janeiro de 2015. Regulamenta a aplicaçâo da Resoluçâo Normativa n 110/2014, do Conselho Nacional de Imigraçăo, que autoriza a concessăo de permanência de caráter provisório, a título especial, a estrangeiros que sejam réus em processos criminais ou estejam cumprindo pena no Território Nacional. Diário Oficial de Uniăo, Brasília, n. 22, 02 fev. 2015. Seçâo 1, p. 41. Disponível em: <http://pesquisa.in.gov.br/imprensa/jsp/visualiza/index.jsp?jornal=1 \&pagina=41\&data=02/02/2015>. Acesso em: 12 out. 2016.

BRASIL. Supremo Tribunal Federal. Habeas Corpus n 97147/MT. Segunda Turma, Relator Min. Ellen Gracie, julgado em 04/08/2009. Disponível em: 〈http://stf.jusbrasil. com.br/jurisprudencia/14712307/habeas-corpus-hc-97147-mt>. Acesso em: 12 out. 2016. 
CUNHA, Manuela Ivone Pereira da. A prisăo e suas novas redundâncias. Direito e Justiça, Lisboa, n. esp., p. 119-125, 2004. Disponível em: <https://repositorium.sdum.uminho. pt/bitstream/1822/5226/3/A\%20pris\%C3\%A3o\%20e\%20as\%20suas\%20novas\%20 redund\%C3\%A2ncias.pdf>. Acesso em: 11 out. 2016.

DIP, Andrea. Maternidade condenada. Săo Paulo, 11 ago. 2014. Disponível em: <http:// apublica.org/2014/08/maternidade-condenada/>. Acesso em: 12 out. 2016.

DUARTE, Nathália. Língua e hábitos culturais complicam a vida de presos estrangeiros. G1 Notícias, Săo Paulo, 24 jun. 2010. Disponível em: <http://g1.globo.com/brasil/ noticia/2010/06/lingua-e-habitos-culturais-complicam-vida-de-presos-estrangeiros. html>. Acesso em: 11 out. 2016.

ESPINOZA, Olga. A prisăo feminina desde um olhar da criminologia feminista. Revista Transdisciplinar de Ciências Penitenciárias. Pelotas, v.1, n. 1, p. 35-38, jan./dez. 2002. Disponível em: <http://docslide.com.br/documents/a-prisao-feminina-desde-um-olharcriminologia-feminista.html>. Acesso em: 10 out. 2016.

FONTELES, Natália. Presas estrangeiras: contexto de violaçôes ainda mais grave nas prisōes brasileiras. Adital: Notícias da América Latina e Caribe, Fortaleza, 28 nov. 2014. Disponível em: <http://site.adital.com.br/site/noticia.php?lang=PT\&prevlang=ES\&cod=83475 $>$. Acesso em 11 out. 2016.

GANDIN, Luís Armando; HYPOLITO, Álvaro Moreira. Dilemas do nosso tempo: globalizaçăo, multiculturalismo e conhecimento. Entrevista com Boaventura de Sousa Santos. Currículo sem Fronteiras, v. 3, n. 2, p. 5-23, jul./dez. 2003. Disponível em: <http://www. boaventuradesousasantos.pt/documentos/curriculosemfronteiras.pdf〉. Acesso em: 11 out. 2016.

HEYWOOD, Andrew. Ideologias políticas: do feminismo ao multiculturalismo. Trad. Janaína Marcoantonio, Mariane Janikain. Sāo Paulo: Ática, 2010.

LEMGRUBER, Julita. Cemitério dos vivos: análise sociológica de uma prisăo de mulheres. 2. ed. Rio de Janeiro: Forense, 1999.

MESSUTI, Ana. El tiempo como pena. Buenos Aires: Ed. Ediar, 2008.

SĂO PAULO. Secretaria de Administraçăo Penitenciária. Penitenciária de Itaí abrigará presos estrangeiros. Sáo Paulo, 16 out. 2016. Disponível em: 〈http://www.sap.sp.gov.br/ common/nota_imp/0001-0099/ni033.html>. Acesso em: 18 out. 2016.

SANTOS, Boaventura de Sousa. NUNES, Joăo Arriscado. Introduçăo: para ampliar o cânone do reconhecimento, da diferença e da igualdade. In: SANTOS, Boaventura de Sousa (org.). Reconhecer para libertar: os caminhos do cosmopolitismo multicultural. Rio de Janeiro: Civilizaçăo Brasileira, 2003 (Série Reinventar a emancipaçăo social: para novos manifestos, v. 3).

SEGUIN, Elida. Minorias e grupos vulneráveis: uma abordagem jurídica. Imprenta: Rio de Janeiro, Forense, 2002.

TAYLOR, Charles. Multiculturalismo: La politica del riconoscimento. Milan: Anabasi, 1993.

TAYLOR, Charles et al. Multiculturalismo: examinando a política de reconhecimento. Traduçáo de Marta Machado. Lisboa: Instituto Piaget, 1997. 
ZAMPIER, Deborah. Regras de Bangkok jogam luz nas mazelas de gênero do sistema penal, diz autora. CNJ: Notícias, Brasília, 12 jun. 2016. Disponível em: <http://www.cnj.jus. br/noticias/cnj/82802-regras-de-bangkok-jogam-luz-nas-mazelas-de-genero-do-sistema-penal-diz-autora>. Acesso em: 12 out. 2016.

RECEBIDO EM: 03/03/2017

APROVADO EM: 22/05/2017 